\title{
PROFILING KECERDASAN EMOSIONAL MAHASISWA
}

\author{
Antonina Pantja Juni Wulandari \\ Jurusan Psikologi, Fakultas Psikologi, Bina Nusantara University \\ Jl. Kemanggisan Ilir III No. 45, Kemanggisan, Palmerah, Jakarta Barat 11480 \\ yunwulan@binus.edu
}

\begin{abstract}
Article pictures the emotional intelligent of college students. The emotional intelligent defines our potential to learn practical skills based on: self awareness, self controlling, motivation, empathy, social skill. From the five skills, it could be devided into two skills, i.e. individual and social competence. Individual competence is based on emotional intelligence about how we manage ourselves. Meanwhile, social competence is about how we handle our relationship with other people. From the research result, it can be concluded that emotional intelligence level of college students should be improved since there is none who has high score, especially about empathy as the lowest score.
\end{abstract}

Keywords: emotional intelligence, college students, psychological measurement

\begin{abstract}
ABSTRAK
Artikel melihat gambaran kecerdasan emosional mahasiswa. Kecerdasan emosi menentukan potensi kita untuk mempelajari keterampilan-keterampilan praktis yang didasarkan pada: kesadaran diri, pengaturan diri, motivasi, empati, ketrampilan sosial. Dari kelima ketrampilan tersebut dapat digolongkan menjadi dua ketrampilan yaitu kecakapan pribadi dan kecakapan sosial. Kecakapan pribadi adalah kecakapan hasil belajar yang didasarkan pada kecerdasan emosi yang menentukan bagaimana kita dapat mengelola diri sendiri. Sedangkan kecakapan sosial adalah kecakapan yang menentukan bagaimana kita menangani suatu hubungan dengan orang lain. Hasil penelitan dapat disimpulkan bahwa tingkat kecerdasan emosi mahasiswa masih perlu ditingkatkan karena tidak ada satupun yang mempunyai score tinggi, terutama yang perlu mendapat perhatian khusus adalah empatinya karena sebagian besar memilik score yang rendah.
\end{abstract}

Kata kunci: kecerdasan emosional, mahasiswa, alat ukur psikologi 


\section{PENDAHULUAN}

Latar belakang penelitian ini adalah untuk mencari gambaran kecerdasan emosional yang dimiliki mahasiswa. Berdasarkan pengamatan peneliti semakin banyaknya mahasiswa yang kurang terampil berinteraksi dan sulit memahami perasaan orang lain. Hal ini terjadi kemungkinannya adalah karena rendahnya dimensi kecerdasan emosional mereka. Konsep tentang kecerdasan emosional bukanlah konsep baru dalam dunia psikologi. Thorndike (1920) sudah mengungkap social intelligence, yaitu kemampuan mengelola hubungan antar pribadi baik pada pria maupun wanita. Thorndike percaya bahwa kecerdasan sosial merupakan syarat penting bagi keberhasilan seseorang di berbagai aspek kehidupannya. Gardner (1984) menyebut tujuh kecerdasan penting pada manusia. Salah satunya adalah kecerdasan interpersonal, yaitu kecerdasan yang memungkinkan individu mampu berhubungan secara harmonis dengan orang lain.

Meyer \& Salovey (dalam Cherniss \& Goleman, 2001) mendefinisikan kecerdasan emosional sebagai kemampuan untuk memahami perasaan diri sendiri, untuk berempati terhadap perasaan orang lain dan untuk mengatur emosi, yang secara bersama berperan dalam peningkatan taraf hidup seseorang. Cooper \& Sawaf (dalam Goleman, 2005) mengatakan bahwa kecerdasan emosional adalah kemampuan merasakan, memahami, dan secara selektif menerapkan daya dan kepekaan emosi sebagai sumber energi dan pengaruh yang manusiawi”.

Menurut Goleman (2005), kecerdasan emosi menentukan potensi kita untuk mempelajari keterampilan-keterampilan praktis yang didasarkan pada: kesadaran diri, pengaturan diri, motivasi, empati, dan ketrampilan sosial. Dari kelimanya dapat digolongkan menjadi dua ketrampilan yaitu kecakapan pribadi dan kecakapan sosial. Kecakapan pribadi adalah kecakapan hasil belajar yang didasarkan pada kecerdasan emosi yang menentukan bagaimana kita dapat mengelola diri sendiri. Sedangkan kecakapan sosial adalah kecakapan yang menentukan bagaimana kita menangani suatu hubungan dengan orang lain.

Individu yang memiliki kecerdasan emosional lebih mampu mengendalikan dan memotivasi diri. Bagi individu ini hidup sangat berarti, memiliki prinsip dan bertanggungjawab terhadap segala sesuatu, mampu mengelola dan menyatakan emosi dengan tepat, bersifat tegas tetapi tetap seimbang (Davis, 2004). Kecerdasan emosional yang dimiliki oleh seseorang, membuat mereka merasa nyaman dengan diri sendiri, orang lain dan lingkungan sosial di mana mereka tinggal (Goleman, 2003). Mereka dapat mengelola stress tanpa rasa takut, suka berteman, spontan, jenaka dan terbuka terhadap pengalaman inderawi. Orang yang tidak memiliki kompetensi kecerdasan emosional akan menghadapi peningkatan sejumlah resiko gangguan fisik dan mental. Mereka juga menghadapi kesulitan dalam berhubungan dengan orang lain, sulit beradaptasi, emosi yang meledak-ledak (mudah marah) sehingga sering terjadi konflik dengan orang lain, pesimis serta mudah putus asa, tidak mudah bergaul sehingga tidak memiliki banyak teman, sehingga walaupun kemampuan intelektualnya tinggi tanpa didukung kecerdasan emosional yang baik, maka sulit untuk mencapai kesuksesan (Martin, 2003).

Tujuan dan manfaat dari penelitian ini adalah mengembangkan sebuah alat ukur kecerdasan emosional, yang mampu mengukur kecerdasan emosional mahasiswa, dan area kecerdasan emosional yang paling lemah yang dimiliki mahasiswa.

\section{METODE}

Desain penelitian ini menggunakan penelitian kuantitatif non-eksperimental. Instrumen yang dipakai adalah alat ukur kecerdasan emosional yang dirancang peneliti. Construct validity alat ukur ini diambil dari definisi operasional kecerdasan emosional dari teori Goleman (2005), yaitu kemampuan seseorang individu menyadari diri, mengatur diri, memotivasi diri, berempati terhadap 
orang lain dan memiliki ketrampilan sosial yang membuatnya mampu berinteraksi dengan orang lain secara tepat. Ada 4 domain yang diukur, domain-domain tersebut dapat dilihat dalam tabel 1.

Tabel 1 Domain Kecerdasan Emosional

\begin{tabular}{|c|c|c|c|}
\hline No. & Domain & Indikator & Definisi Operasional \\
\hline \multirow[t]{17}{*}{1.} & \multirow{17}{*}{$\begin{array}{l}\text { Kecakapan } \\
\text { Pribadi }\end{array}$} & \multirow[t]{6}{*}{ Kesadaran emosi } & Mengenali emosi diri sendiri dan efeknya. \\
\hline & & & $\begin{array}{l}\text { Orang yang unggul kesadaran emosi akan menunjukkan ciri sebagai } \\
\text { berikut: }\end{array}$ \\
\hline & & & 1. Tahu emosi mana yang sedang dirasakan dan mengapa. \\
\hline & & & $\begin{array}{l}\text { 2. Menyadari keterkaitan antara perasaan dengan pikiran, perbuatan } \\
\text { serta perkataan diri sendiri. }\end{array}$ \\
\hline & & & 3. Mengetahui bagaimana perasaan mempengaruhi kinerja. \\
\hline & & & $\begin{array}{l}\text { 4. Mempunyai kesadaran yang menjadi pedoman untuk nilai-nilai } \\
\text { dan sasaran-sasaran. }\end{array}$ \\
\hline & & \multirow[t]{6}{*}{ Penilaian diri } & $\begin{array}{l}\text { Mengetahui sumber daya batiniah, kemampuan dan keterbatasan diri } \\
\text { sendiri }\end{array}$ \\
\hline & & & Orang dengan kecakapan ini akan: \\
\hline & & & $\begin{array}{l}\text { 1. Sadar tentang kekuatan-kekuatan dan kelemahan-kelemahan } \\
\text { sendiri }\end{array}$ \\
\hline & & & 2. Menyempatkan diri untuk merenung, belajar dari pengalaman. \\
\hline & & & $\begin{array}{l}\text { 3. Terbuka terhadap umpan balik yang tulus, bersedia menerima } \\
\text { perspektif baru, mau terus belajar dan mengembangkan diri. }\end{array}$ \\
\hline & & & $\begin{array}{l}\text { 4. Mampu menunjukkan rasa humor dan bersedia memandang diri } \\
\text { sendiri dengan perspektif yang luas. }\end{array}$ \\
\hline & & \multirow[t]{5}{*}{ Percaya diri } & Keyakinan tentang harga diri dan kemampuan sendiri. \\
\hline & & & Orang dengan kecakapan ini akan: \\
\hline & & & $\begin{array}{l}\text { 1. Berani tampil dengan keyakinan diri, berani menyatakan } \\
\text { keberadaannya. }\end{array}$ \\
\hline & & & $\begin{array}{l}\text { 2. Berani menyuarakan pandangan yang tidak populer dan bersedia } \\
\text { berkorban demi kebenaran. }\end{array}$ \\
\hline & & & $\begin{array}{l}\text { 3. Tegas, mampu membuat keputusan yang baik walaupun dalam } \\
\text { keadaan tidak pasti dan tertekan. }\end{array}$ \\
\hline \multirow[t]{14}{*}{2.} & \multirow[t]{14}{*}{$\begin{array}{l}\text { Pengaturan } \\
\text { Diri }\end{array}$} & \multirow[t]{5}{*}{ Kendali diri } & $\begin{array}{l}\text { Mengelola emosi-emosi dan desakan-desakan hati yang dapat } \\
\text { merusak dapat terkendali. }\end{array}$ \\
\hline & & & Orang dengan kecakapan ini akan: \\
\hline & & & $\begin{array}{l}\text { 1. Mengelola dengan baik perasaan-perasaan impulsif dan emosi } \\
\text { yang menekan mereka. }\end{array}$ \\
\hline & & & $\begin{array}{l}\text { 2. Tetap teguh, tetap positif dan tidak goyah bahkan dalam situasi } \\
\text { yang paling keras. }\end{array}$ \\
\hline & & & 3. Berpikir dengan jernih dan tetap terfokus kendati dalam tekanan. \\
\hline & & \multirow[t]{5}{*}{$\begin{array}{l}\text { Sifat dapat } \\
\text { dipercaya }\end{array}$} & $\begin{array}{l}\text { Memelihara norma kejujuran dan integritas, maksudnya adalah } \\
\text { menunjukkan integritas dan sikap bertanggungjawab dalam } \\
\text { mengelola diri. }\end{array}$ \\
\hline & & & Orang dengan kecakapan ini akan: \\
\hline & & & $\begin{array}{l}\text { 1. Bertindak menurut etika dan tidak pernah mempermalukan orang. } \\
\text { 2. Membangun kepercayaan lewat kendali diri }\end{array}$ \\
\hline & & & $\begin{array}{l}\text { 3. Mengakui kesalahan sendiri dan berani menegur perbuatan tidak } \\
\text { etis orang lain. }\end{array}$ \\
\hline & & & $\begin{array}{l}\text { 4. Berpegang pada prinsip secara teguh bahkan bila akibatnya } \\
\text { adalah menjadi tidak disukai. }\end{array}$ \\
\hline & & \multirow{4}{*}{$\begin{array}{l}\text { Bersifat sungguh- } \\
\text { sungguh }\end{array}$} & Bertanggungjawab atas kinerja pribadi \\
\hline & & & Orang dengan kecakapan ini akan: \\
\hline & & & 1. Memenuhi komitmen dan mematuhi janji. \\
\hline & & & $\begin{array}{l}\text { 2. Bertanggungjawab sendiri untuk memperjuangkan tujuan. } \\
\text { 3. Terorganisasi dan cermat dalam bekerja. }\end{array}$ \\
\hline
\end{tabular}


Tabel 1 Domain Kecerdasan Emosional (lanjutan)

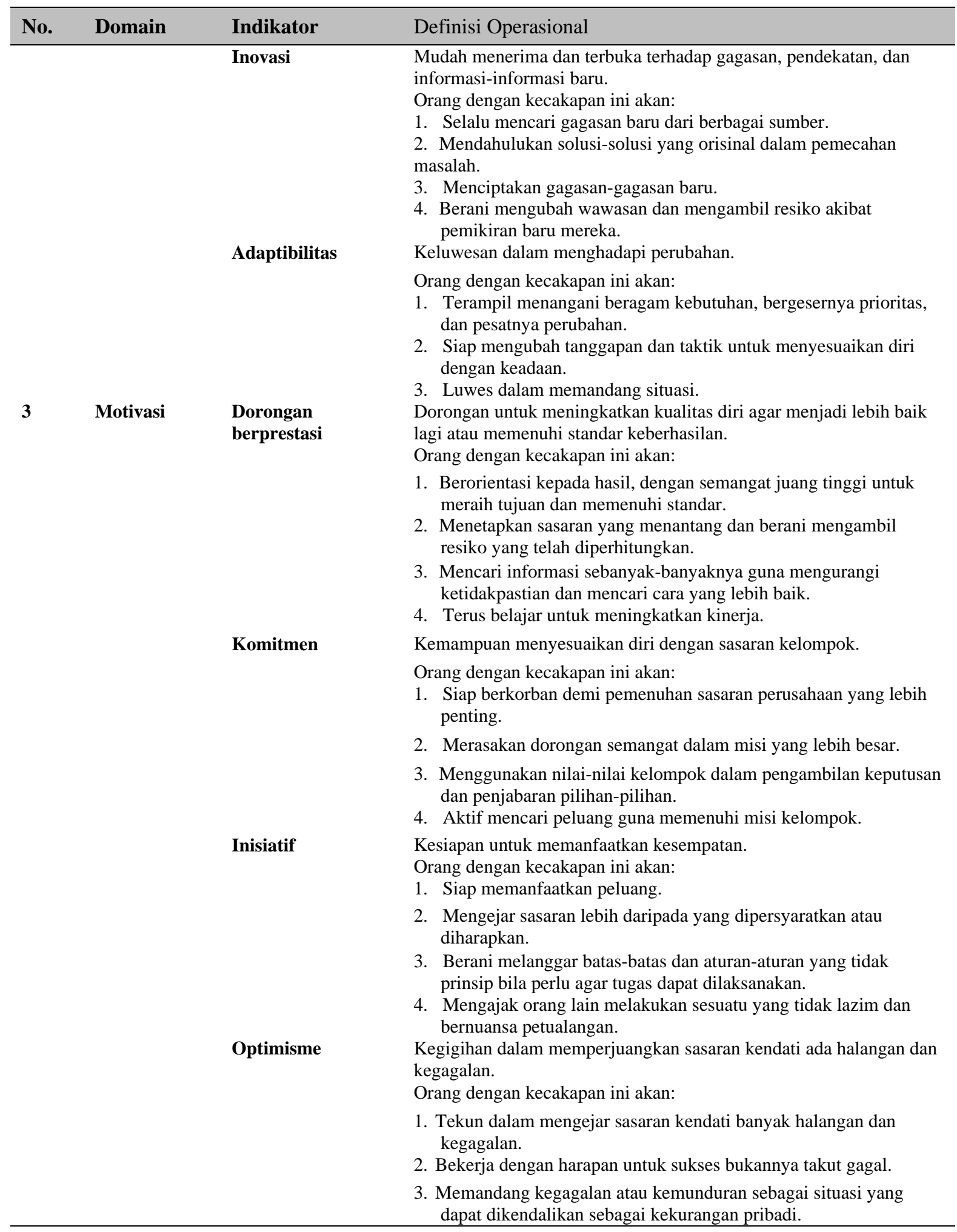


Tabel 1 Domain Kecerdasan Emosional (lanjutan)

\begin{tabular}{|c|c|c|c|}
\hline No. & Domain & Indikator & Definisi Operasional \\
\hline \multirow[t]{21}{*}{4} & \multirow[t]{21}{*}{ Empati } & \multirow[t]{3}{*}{$\begin{array}{l}\text { Memahami orang } \\
\text { lain }\end{array}$} & $\begin{array}{l}\text { Kemampuan mengindera perasan dan perpektif orang lain, dan } \\
\text { menunjukkan minat aktif terhadap kepentingan orang lain. }\end{array}$ \\
\hline & & & Orang dengan kecakapan ini akan: \\
\hline & & & $\begin{array}{l}\text { 1. Memperhatikan syarat-syarat emosi dan mendengarkannya } \\
\text { dengan baik. } \\
\text { 2. Menunjukkan kepekaan dan pemahaman terhadap perpektif orang } \\
\text { lain. } \\
\text { 3. Membantu berdasarkan pemahaman terhadap kebutuhan dan } \\
\text { perasaan orang lain. }\end{array}$ \\
\hline & & \multirow[t]{2}{*}{$\begin{array}{l}\text { Orientasi } \\
\text { pelayanan }\end{array}$} & $\begin{array}{l}\text { Mengantisipasi, mengenali, dan berusaha memenuhi kebutuhan orang } \\
\text { lain. } \\
\text { Orang dengan kecakapan ini akan: }\end{array}$ \\
\hline & & & $\begin{array}{l}\text { 1. Memahami kebutuhan-kebutuhan orang lain. } \\
\text { 2. Mencari berbagai cara untuk meningkatkan kepuasan dalam } \\
\text { berinteraksi } \\
\text { 3. Dengan senang hati menawarkan bantuan yang sesuai }\end{array}$ \\
\hline & & \multirow[t]{5}{*}{$\begin{array}{l}\text { Mengembangkan } \\
\text { orang lain }\end{array}$} & $\begin{array}{l}\text { Merasakan kebutuhan orang lain untuk berkembang dan } \\
\text { meningkatkan kemampuan orang lain. }\end{array}$ \\
\hline & & & Orang dengan kecakapan ini akan: \\
\hline & & & $\begin{array}{l}\text { 1. Mengakui dan menghargai kekuatan, keberhasilan dan } \\
\text { perkembangan orang lain }\end{array}$ \\
\hline & & & $\begin{array}{l}\text { 2. Menawarkan umpanbalik yang bermanfaat dan mengidentifikasi } \\
\text { kebutuhan orang lain untuk berkembang }\end{array}$ \\
\hline & & & $\begin{array}{l}\text { 3. Menjadi mentor dengan memberikan pelatihan pada waktu yant } \\
\text { tepat dan penugasan-penugasan yang menantang serta membuat } \\
\text { orang lain terampil. }\end{array}$ \\
\hline & & \multirow[t]{6}{*}{$\begin{array}{l}\text { Mengatasi } \\
\text { keragaman }\end{array}$} & $\begin{array}{l}\text { Menumbuhkan peluang melalui pergaulan dengan bermacam-macam } \\
\text { orang. }\end{array}$ \\
\hline & & & Orang dengan kecakapan ini akan: \\
\hline & & & $\begin{array}{l}\text { 1. Hormat dan mau bergaul dengan orang-orang dari bermacam- } \\
\text { macam latar belakang }\end{array}$ \\
\hline & & & $\begin{array}{l}\text { 2. Memahami beragamnya pandangan dan peka terhadap perbedaan } \\
\text { antar kelompok }\end{array}$ \\
\hline & & & $\begin{array}{l}\text { 3. Memandang keragaman sebagai peluang, menciptakan } \\
\text { lingkungan yang memungkinkan semua orang sama-sama maju } \\
\text { kedati berbeda-beda. }\end{array}$ \\
\hline & & & 4. Berani menentang sikap membeda-bedakan dan intoleransi \\
\hline & & \multirow[t]{5}{*}{ Kesadaran politis } & $\begin{array}{l}\text { Kemampuan membaca arus-arus emosi sebuah kelompok dan } \\
\text { hubungannya dengan kekuasaan atau kemampuan membaca situasi } \\
\text { sosial dan politik. }\end{array}$ \\
\hline & & & Orang dengan kecakapan ini akan: \\
\hline & & & 1. Membaca dengan cermat hubungan kekuasaan yang paling tinggi \\
\hline & & & 2. Mengenal dengan baik semua jaringan sosial yang penting \\
\hline & & & $\begin{array}{l}\text { 3. Memahami kekuatan-kekuatan yang membentuk pandangan- } \\
\text { pandangan serta tindakan-tindakan dalam masyarakat }\end{array}$ \\
\hline \multirow[t]{6}{*}{5} & \multirow{6}{*}{$\begin{array}{l}\text { Ketrampilan } \\
\text { Sosial }\end{array}$} & \multirow[t]{6}{*}{ Pengaruh } & Memiliki taktik-taktik untuk melakukan persuasi \\
\hline & & & Orang dengan kecakapan ini akan: \\
\hline & & & 1. Terampil dalam persuasi. \\
\hline & & & 2. Menyesuaikan presentasi untuk menarik hati pendengar. \\
\hline & & & $\begin{array}{l}\text { 3. Menggunakan strategi yang rumit seperti memberi pengaruh } \\
\text { tidak langsung untuk membangun konsensus dan dukungan. }\end{array}$ \\
\hline & & & $\begin{array}{l}\text { 4. Memadukan dan menyelaraskan peristiwa-peristiwa dramatis } \\
\text { agar menghasilkan sesuatu secara efektif. }\end{array}$ \\
\hline
\end{tabular}


Tabel 1 Domain Kecerdasan Emosional (lanjutan)

\begin{tabular}{|c|c|c|c|}
\hline No. & Domain & Indikator & Definisi Operasional \\
\hline & & \multirow[t]{2}{*}{ Komunikasi } & $\begin{array}{l}\text { Mengirimkan pesan yang jelas dan menyakinkan dan mendengarkan secara } \\
\text { seksama. } \\
\text { Orang dengan kecakapan ini akan: }\end{array}$ \\
\hline & & & $\begin{array}{l}\text { 1. Efektif dalam memberi dan menerima, menyertakan isyarat emosi dalam } \\
\text { pesan-pesan orang lain. } \\
\text { 2. Menghadapi masalah-masalah sulit tanpa ditunda. } \\
\text { 3. Mendengarkan dengan baik, berusaha saling memahami dan bersedia } \\
\text { berbagi informasi secara utuh. } \\
\text { 4. Menggalakkan komunikasi terbuka dan tetap bersedia menerima kabar } \\
\text { buruk sebagaimana kabar baik. }\end{array}$ \\
\hline & & Kepemimpinan & $\begin{array}{l}\text { Membangkitkan inspirasi dan memandu kelompok dan orang lain } \\
\text { Orang dengan kecakapan ini akan: } \\
\text { 1. Mengartikulasikan dan membangkitkan semangat untuk meraih visi serta } \\
\text { misi bersama. } \\
\text { 2. Melangkah di depan untuk memimpin bila diperlukan, tidak peduli } \\
\text { sedang dimana. } \\
\text { 3. Memandu kinerja orang lain namun tetap memberikan tanggungjawab } \\
\text { kepada mereka. } \\
\text { 4. Memimpin lewat teladan. }\end{array}$ \\
\hline & & \multirow{3}{*}{$\begin{array}{l}\text { Katalisator } \\
\text { perubahan }\end{array}$} & Memulai dan mengelola perubahan \\
\hline & & & Orang dengan kecakapan ini akan: \\
\hline & & & $\begin{array}{l}\text { 1. Menyadari perlunya perubahan dan dihilangkannya hambatan. } \\
\text { 2. Menantang status quo untuk menyatakan perlunya perubahan. } \\
\text { 3. Menjadi pelopor perubahan dan mengajak orang lain kedalam perjuangan } \\
\text { itu. }\end{array}$ \\
\hline & & \multirow{2}{*}{$\begin{array}{l}\text { Manajemen } \\
\text { konflik }\end{array}$} & $\begin{array}{l}\text { 4. Membuat model perubahan seperti yang diharapkan orang lain. } \\
\text { Merundingkan dan meyelesaikan ketidaksepakatan. }\end{array}$ \\
\hline & & & $\begin{array}{l}\text { Orang dengan kecakapan ini akan: } \\
\text { 1. Menanggani orang-orang sulit dan situasi tegang dengan diplomasi dan } \\
\text { taktik. } \\
\text { 2. Mengidentifikasi hal-hal yang berpotensi menjadi konflik, menyelesaikan } \\
\text { perbedaan pendapat serta terbuka, dan membantu mendinginkan situasi. } \\
\text { 3. Menganjurkan debat dan diskusi secara terbuka. } \\
\text { 4. Mengantar ke solusi menang-menang }\end{array}$ \\
\hline & & \multirow[t]{3}{*}{$\begin{array}{l}\text { Pengikat } \\
\text { jaringan }\end{array}$} & $\begin{array}{l}\text { Menumbuhkan hubungan sebagai alat } \\
\text { Orang dengan kecakapan ini akan: }\end{array}$ \\
\hline & & & $\begin{array}{l}\text { 1. Menumbuhkan dan memelihara jaringan tidak formal yang meluas. } \\
\text { 2. Mencari hubungan-hubungan yang saling menguntungkan. }\end{array}$ \\
\hline & & & $\begin{array}{l}\text { 3. Membangun hubungan saling percaya dan memelihara keutuhan anggota. } \\
\text { 4. Membangun dan memelihara persahabatan pribadi di antara sesama mitra } \\
\text { kerja. }\end{array}$ \\
\hline & & \multirow{2}{*}{$\begin{array}{l}\text { Kolaborasi dan } \\
\text { kooperasi }\end{array}$} & Berkerja sama dengan orang lain demi tujuan bersama. \\
\hline & & & $\begin{array}{l}\text { Orang dengan kecakapan ini akan: } \\
\text { 1. Menyeimbangkan pemusatan perhatian kepada tugas dengan perhatian } \\
\text { kepada hubungan. } \\
\text { 2. Kolaborasi, berbagai rencana, informasi, dan sumbernya. } \\
\text { 3. Mendeteksi dan menumbuhkan peluang-peluang untuk kolaborasi. } \\
\text { Menciptakan sinergi kelompok dalam memperjuangkan tujuan bersama. }\end{array}$ \\
\hline & & Kemampuan tim & $\begin{array}{l}\text { Orang dengan kecakapan ini akan: } \\
\text { 1. Menjadi teladan dalam kualitas tim seperti respek, kesediaan membantu } \\
\text { orang lain, dan kooperasi. } \\
\text { 2. Mendorong setiap anggota tim agar berpartisipasi secara aktif dan penuh } \\
\text { antusiasme. } \\
\text { 3. Membantu identitas tim, semangat kebersamaan dan komitmen. }\end{array}$ \\
\hline
\end{tabular}


Realibilitas menggunakan Cronbach's Alpha, dengan reabilitas alat ukur kecerdasan emosinal ini adalah 0,698, sedangkan reabilitas masing-masing domain dapat dilihat dalam tabel 2 Uji realibilitas yang dilakukan dengan membuang koefisien korelasi item yang kurang dari 0,2.

Tabel 2 Realibilitas Alat Ukur Kecerdasan Emosi

\begin{tabular}{cll}
\hline No. & Domain & Realibilitas \\
\hline 1 & Kecakapan Pribadi & 0,469 \\
2 & Pengaturan Diri & 0,705 \\
3 & Motivasi & 0,721 \\
4 & Empati & 0,804 \\
5 & Ketrampilan Sosial & 0,793 \\
\hline
\end{tabular}

Alat ukur yang dijadikan instrrumen berupa kuesioner yang sudah diuji dahulu validas dan reabilitasnya sejumlah 183 pertanyaan dan menggunakan skala Likert dengan bobot 1 sampai dengan 5. Kriteria pembobotan dapat dilihat dalam tabel 3.

Tabel 3 Pembobotan Pernyataan dalam Alat Ukur Kecerdasan Emosi

\begin{tabular}{llc}
\hline No. & \multicolumn{1}{c}{ Pernyataan } & Bobot \\
\hline 1. & Sangat tidak sesuai & 1 \\
2. & Tidak sesuai & 2 \\
3. & Ragu-ragu & 3 \\
4. & Sesuai & 4 \\
5. & Sangat sesuai & 5 \\
\hline
\end{tabular}

Populasi sampel dalam penelitian ini adalah mahasiswa Perguruan Tinggi Swasta di Jakarta Barat. Tekhnik pengambilan sampel menggunakan proportionate stratified random sampling. Subyek yang dijadikan sampel penelitian adalah mahasiswa jurusan akuntansi dan manajemen di STIE Trisakti dan Universitas Bina Nusantara. Total sampel yang diambil adalah 85 orang, 45 orang mahasiswa Universitas Bina Nusantara dan 40 orang mahasiswa STIE Trisakti. Menurut usia perkembangan subyek dapat dikategorikan sebagai orang yang sedang memasuki masa dewasa awal.

\section{HASIL DAN PEMBAHASAN}

\section{Profil Subyek Penelitian}

Umur rata-rata subyek adalah 18 tahun. Gambaran umur subyek dapat dilihat dalam tabel 4.

Tabel 4 Usia Subyek

\begin{tabular}{ccc}
\hline Usia & Jumlah & Prosentase \\
\hline 17 tahun & 5 & $6 \%$ \\
18 tahun & 34 & $40 \%$ \\
19 tahun & 34 & $40 \%$ \\
20 tahun & 8 & $9 \%$ \\
21 tahun & 3 & $4 \%$ \\
25 tahun & 1 & $1 \%$ \\
Total & 85 & $100 \%$ \\
\hline
\end{tabular}


Jenis kelamin subyek terbanyak adalah perempuan yaitu sebanyak 49 orang dan subyek lakilaki sebanyak 36 orang, Gambaran lebih jelas dalam tabel 5.

Tabel 5 Jenis Kelamin Subyek

\begin{tabular}{lcc}
\multicolumn{1}{c}{ Jenis Kelamin } & Jumlah & Prosentase \\
\hline Perempuan & 49 & $58 \%$ \\
Laki-laki & 36 & $42 \%$ \\
Total & 85 & $100 \%$ \\
\hline
\end{tabular}

\section{Gambaran Kecerdasan Emosional Subyek}

\section{Karakteristik Kecerdasan Emosional Subyek}

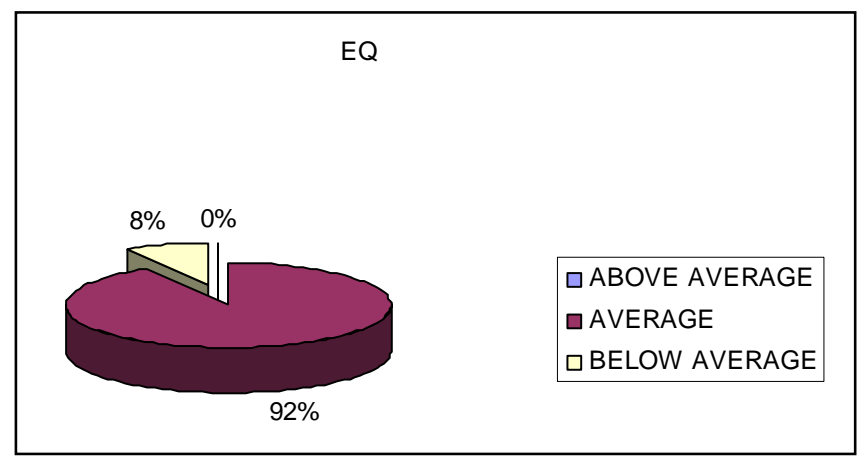

Gambar 1 Diagram kecerdasan emosional subyek

Dari Gambar 1, dapat terlihat bahwa kecerdasan emosi terbanyak masih pada tingkat rata-rata yaitu sebanyak 92\%, sedangkan yang memiliki kercerdasan emosional yang di bawah rata-rata ada $8 \%$. Dan tidak ada satupun subyek yang memiliki kecerdasan emosi tinggi.

\section{Karakteristik Kesadaran Diri Subyek}

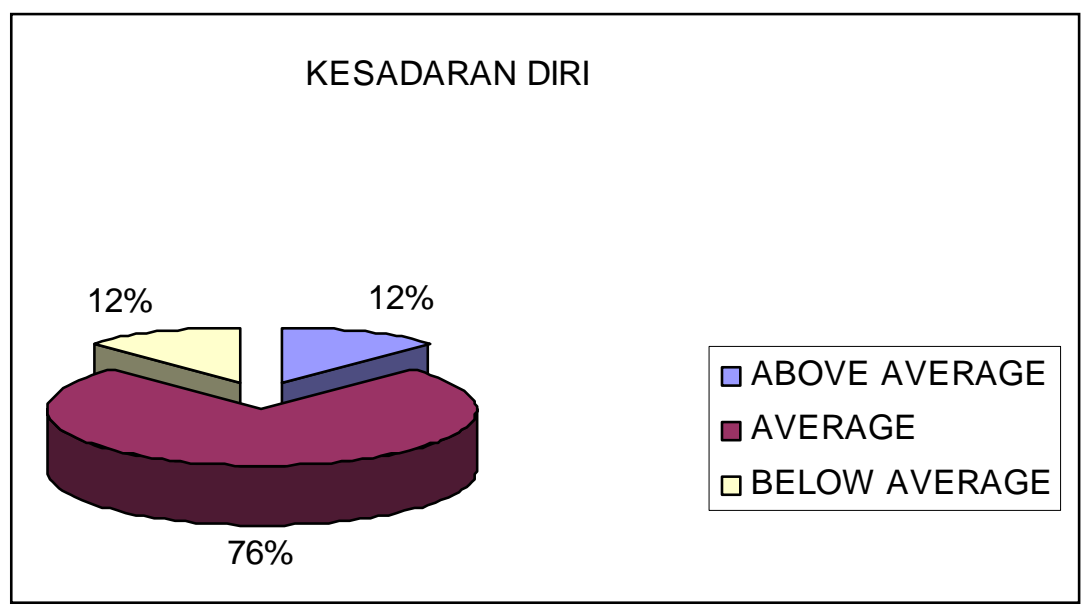

Gambar 2 Diagram kesadaran diri subyek 
Dari Gambar 2 dapat terlihat bahwa tingkat kesadaran diri subyek terbanyak masih pada tingkat average yaitu sebanyak $76 \%$ sedangkan yang memiliki kesadaran diri yang diatas rata-rata hanya sebesar $12 \%$.

\section{Karakteristik Pengaturan Diri Subyek}

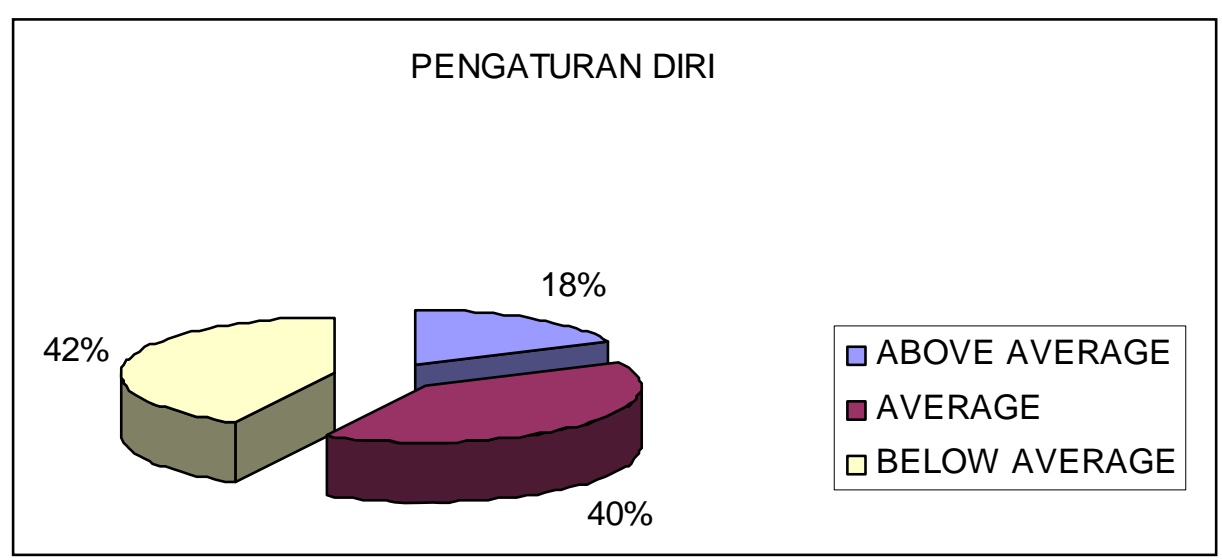

Gambar 3 Diagram pengaturan diri subyek

Dari Gambar 3, dapat terlihat bahwa pengaturan diri subyek terbanyak masih pada tingkat below average yaitu sebanyak $42 \%$ sedangkan yang memiliki pengaturan diri yang di atas rata-rata hanya sebesar $18 \%$ saja.

\section{Karakteristik Motivasi Subyek}

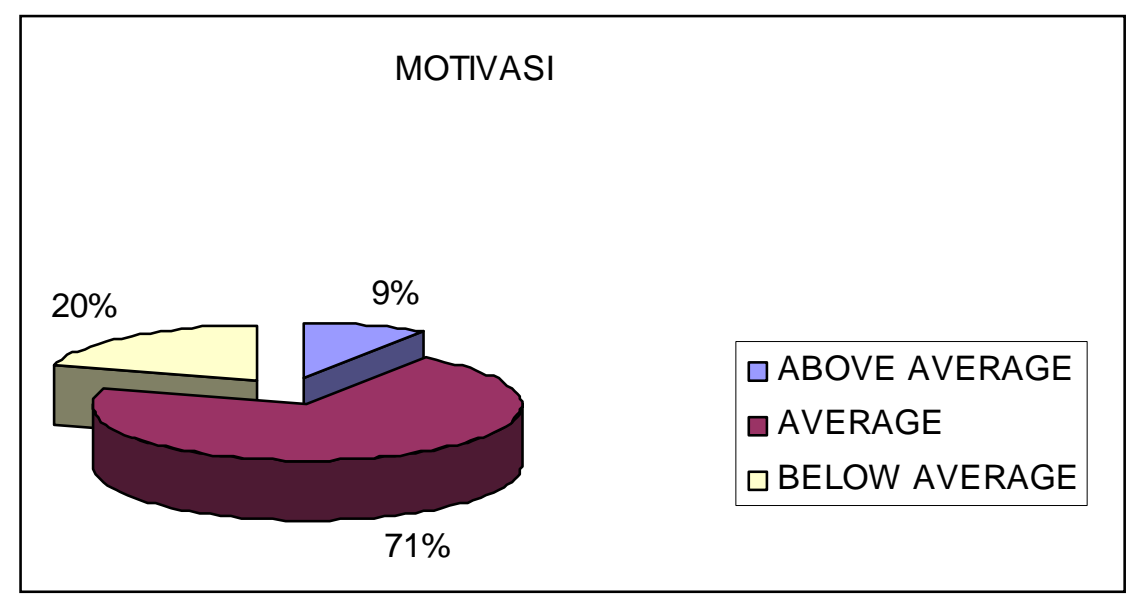

Gambar 4 Diagram motivasi obyek

Dari Gambar 4, dapat terlihat bahwa motivasi subyek terbanyak masih pada tingkat rata-rata yaitu sebanyak $71 \%$ sedangkan yang memiliki motivasi diatas rata-rata hanya sebesar $12 \%$. 


\section{Karakteristik Ketrampilan Sosial Subyek}

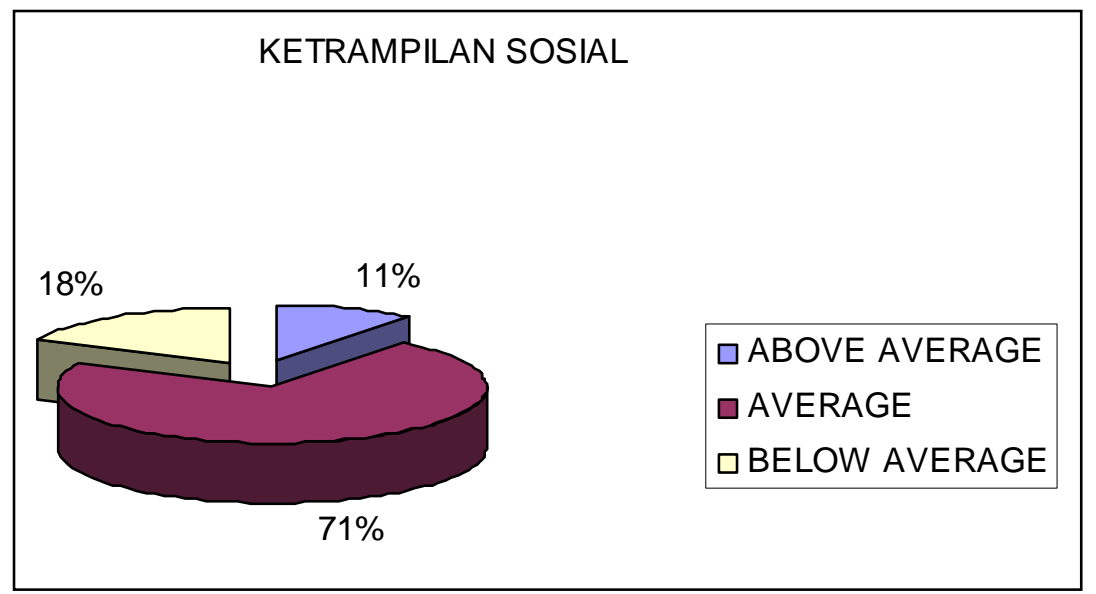

Gambar 5 Diagram ketrampilan sosial subyek

Dari Gambar 5, dapat terlihat bahwa tingkat ketrampilan sosial subyek terbanyak masih pada tingkat average yaitu sebanyak $71 \%$ sedangkan yang memiliki ketrampilan sosial di atas rata-rata hanya sebesar $11 \%$.

\section{Karakteristik Empati Subyek}

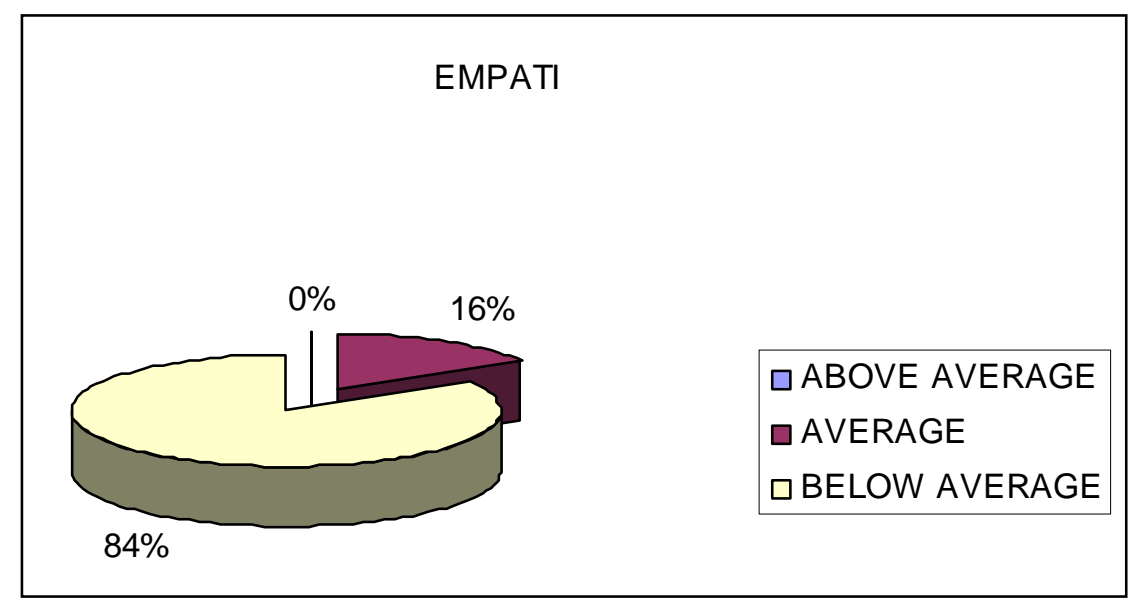

Gambar 6 Diagram empati subyek

Dari Gambar 6 dapat terlihat bahwa empati subyek rendah terlihat ada 84\% berada pada tingkat below average. Sedangkan di tingkat average rata-ratanya sebanyak $16 \%$ dan tidak ada yang berada diatas rata-rata.

\section{PENUTUP}

Dari hasil penelitan dapat disimpulkan bahwa kecerdasan emosi terbanyak masih pada tingkat rata-rata yaitu sebanyak 92\%, sedangkan yang memiliki kercerdasan emosional yang dibawah rata-rata ada $8 \%$. Dan tidak ada satupun subyek yang memiliki kecerdasan emosi tinggi. Tingkat kesadaran diri subyek terbanyak masih pada tingkat average yaitu sebanyak $76 \%$ sedangkan yang memiliki 
kesadaran diri yang diatas rata-rata hanya sebesar $12 \%$. Pengaturan diri subyek terbanyak masih pada tingkat below average yaitu sebanyak $42 \%$ sedangkan yang memiliki pengaturan diri yang diatas ratarata hanya sebesar $18 \%$ saja. Motivasi subyek terbanyak masih pada tingkat average yaitu sebanyak $71 \%$ sedangkan yang memiliki motivasi diatas rata-rata hanya sebesar $12 \%$. Tingkat ketrampilan sosial subyek terbanyak masih pada tingkat average yaitu sebanyak $71 \%$ sedangkan yang memiliki ketrampilan sosial diatas rata-rata hanya sebesar $11 \%$. Empati subyek rendah terlihat ada $84 \%$ berada pada tingkat below average. Sedangkan di tingkat average sebanyak $16 \%$ dan tidak ada yang berada diatas rata-rata. Gambaran ini memperlihatkan bahwa tingkat kecerdasan emosi mahasiswa masih perlu ditingkatkan karena tidak ada satupun yang mempunyai score tinggi, terutama yang perlu mendapat perhatian khusus adalah empatinya karena sebagian besar memilik score yang rendah.

\section{DAFTAR PUSTAKA}

Cherniss, C., \& Goleman, D. ( 2001). The emotionally intelligent workplace: How to select for measure, and improve emotional intelligence in individuals, group, and organization. New York: Jossey-Bass.

Davis, M. (2004). Uji dan asah EQ anda: Mengetahui tingkat kecerdasan emosional anda. Jakarta: Harmoni.

Gardner, H. (1984). Frames of Mind: The theory of multiple intelligences. London: Heinemann.

Goleman, D. (2005). Working with emotional intelligence: Kecerdasan emosi untuk mencapai puncak prestasi. Jakarta: Gramedia Pustaka Utama.

Goleman, D. (2003). Emotional intelligenc - Kecerdasan emosi: Mengapa EI lebih penting daripada IQ. Jakarta: Gramedia Pustaka Utama.

Martin, A. D. (2003). Emotional quality management: Refleksi, revisi dan revitalisasi hidup melalui kekuatan emosi. Jakarta: Arga.

Thorndike, E.L. (1920). Intelligence and its use. Harper's Magazine, 140, 227-235. 